\title{
Ergenlerde Çevresel Risk Algısının Belirlenmesi
}

Determining the Environmental Risk Perception of Adolescents

\author{
Adile TÜMER ${ }^{1}$, Adem SÜMEN $^{2}$
}

\section{öz}

Araştırma ergenlerin çevresel risk algısını ve bazı değişkenlerle ilişkisini incelenmek amacıyla yapılmıştır.

Tanımlayıcı ve kesitsel tipte tasarlanan bu araştırma 2015 yılında Muğla'da iki farklı lisede yapılmıştır $(\mathrm{N}=525)$. Örnekleme yöntemine gidilmemiş, çalışmaya katılmayı kabul eden ve yazılı izin alınan 473 öğrenciden veri toplanmıştır. Veri toplama aracı olarak, "Tanımlayıcı özellikler soru formu" ve "Çevresel Risk Algısı Ölçeği”” kullanılmıştır. Verilerin değerlendirmesi SPSS 20,0 paket programında, tanımlayıcı istatistikler, bağımsız guruplarda t testi ve tek yönlü varyans analizi ile yapılmıştır. Araştırma için ölçek kullanım izni, etik kurul izni, araştırmanın yapıldığı kurumdan ve öğrencilerden yazılı izin alınmıştır.

Araştırma kapsamına alınan öğrencilerin yaş ortalaması 16,22 $\pm 1,07$ ve \%70,2'si kız öğrencidir. Öğrencilerin \%74,8'inin ailesinde çevre konusunun konuşulduğu, \%72,7'sinin konuyu ilgi çekici bulduğu ve \%50,3'ünün derslerde çevre konusunun işlendiğini ifade ettiği belirlenmiştir. Araştırmada öğrencilerin Çevresel Risk Algısı Ölçeği puan ortalamasının $5,75 \pm 1,23$ olduğu saptanmıştır. Sınıf düzeyi, gelir durumu, çevre konusunun ilgisini çekmesi, ailede çevre konusunun konuşulması ve lisedeki derslerde işleniyor olması gibi bağımsı değişkenlere göre çevresel risk algısı puan ortalamasında anlamlı fark belirlenmiştir $(\mathrm{p}<0,05)$.

Öğrencilerin çevresel risk algısının iyi düzeyde olduğu; ailede ve okulda çevre konusunun ele alınıyor olmasının bu algıyı daha da güçlendirdiği söylenebilir. Tüm okul müfredatlarında çevre sağlı̆̆ı derslerinin olması ve yaygınlaştırılmasının, konuyla ilgili farkındalığı artıracağı, dolayısıyla toplum sağlığına katkı sağlayacağı düşünülmektedir.

Anahtar Kelimeler: Çevre, Çevre sağ lığı, Ergen.

\section{ABSTRACT}

This study aimed to examine the environmental risk perception of adolescents and its relationship with some variables.

This descriptive and cross-sectional study was conducted in two different high schools in Muğla in 2015. Samples were not selected; instead, data were obtained from 473 students who agreed to participate. The data were collected using a "Descriptive Characteristics Questionnaire" and the "Environmental Risk Perception Scale." The data were analyzed using descriptive statistics, independent group t-tests, and one-way analysis of variance. Permission to implement the scale, ethical committee approval, institutional permissions, and written permission from students were obtained.

The mean age of students was $16.22 \pm 1.07$ years, and $70.2 \%$ of them were female. Of the students, $74.8 \%$ said that the subject of the environment was discussed in their family, and $72.7 \%$ said that they were interested in this subject. The mean score of students on the Environmental Risk Perception Scale was 5.75 \pm 1.23 . The three highest risks perceived by the students were canalization, radiation, and hazardous waste. The three lowest risks perceived by the students were overgrazing, commercial fishery, and sportive hunting. Class level, income level, being interested in the environment, discussing the environment in family settings, and learning about these subjects in classes in high school affected the mean scores of environmental risk perception $(\mathrm{p}<0.05)$.

Students had good levels of environmental risk perception. This might have been strengthened by the fact that this subject is taught in school and discussed in the students' families. All school syllabi should include the subject of environmental health and generalize the information to increase student awareness of this subject. This may contribute to community health.

Keywords: Environment, Environmental health, Adolescent.

Ulusal Halk Să̆lı̆̆ Hemşireliği Kongresi’nde poster bildiri olarak sunulmuştur. 17-20 Haziran 2015, İzmir, Türkiye.

Muğla Sitkı Koçman Üniversitesi Bilimsel Araştırmalar ve Yayın Etiği Kurulu’ndan etik kurul izni (Tarih: 07.01.2015, Karar no: 1) alınmıştır.

${ }^{1}$ Dr. Öğr. Üyesi Adile TÜMER Muğla Sıtkı Koçman Üniversitesi, Sağlık Bilimleri Fakültesi, Hemşirelik Bölümü, Halk Sağlığı Hemşireliği Anabilim Dali, tadile@mu.edu.tr, ORCID: 0000-0002-3078-6468

${ }^{2}$ Öğr. Gör. Dr. Adem SÜMEN, Akdeniz Üniversitesi, Kumluca Sağlık Bilimleri Fakültesi, Hemşirelik Bölümü, Halk Sağlığı Hemşireliği Anabilim Dal1, ademsumen@akdeniz.edu.tr, ORCID: 0000-0002-8876-400X 
Çevre, yaşamsal faaliyetlerin sürdüğü ve canlıların karşılıklı etkileşim içerisinde bulundukları yaşam ortamı olarak tanımlanmaktadır. Sağlıklı bir çevrede yaşamak herkesin sahip olması gereken bir haktır fakat çağımızın en önemli konularından biri de çevre sorunlarıdır. ${ }^{1,2}$ Günümüzde herkes ekolojik dengedeki bozulmadan, hızlı nüfus artışından, endüstrileşme ve kaynakların sınırsız bir şekilde kullanılmasından, nükleer santrallerden kaynaklanan radyoaktif kirlenmelerden, hormonlu besinlerden, suyun kirlenmesinden, doğal kaynakların tükenmesinden, bitki ve hayvan türlerinin yok olmasından yakınmaktadır. ${ }^{3}$

Çevresel problemlerin ortaya çıkardığı sorunlar çevre sağlığını, dolayısıyla toplum sağlığını olumsuz etkilemektedir. ${ }^{4}$ Halk sağlığı hemşireleri, sağlık ihtiyaçlarının sürekli değişmesi karşısında eğitim, danışmanlık, araştırma, liderlik fonksiyonlarını daha geniş kapsamlı ve etkili olarak yerine getirmelidir. Çevre sorunlarının doğru ve zamanında çözümlenmesi insanların daha sağlıklı, güvenli bir çevrede yaşamalarını sağlayacaktır. ${ }^{5,6}$ Toplumdaki bütün bireyler çevresel risklerin farkında olup, çevreyi koruma duyarlılığına sahip olması ve çaba göstermesi toplumsal bir görevdir. ${ }^{7}$

\section{GİRIŞ}

Çevre kaynaklı sorunlarla mücadelede çevreye karşı sorumlu bireyler yetiştirmek en etkili ve kalıcı çözümdür. ${ }^{8,9}$ Tüm bireylerin hedef kitleyi oluşturduğu çevre eğitimde amaç, çevre koruma davranışının geliştirilmesi olmalıdır. Bunun yanında çevre risk algisı yüksek olan, bunu tutum ve davranışa dönüştürebilecek bireylerin yetiştirilmesi hedeflenmelidir. Duyarlı ve bilinçli bir toplumun oluşması için çevre eğitimi küçük yaşlardan itibaren verilmelidir. ${ }^{10}$

Okul öncesi eğitimden başlayarak müfredat programlarında çevre ve doğayla ilgili ayrı bir ders bulunmamakta olup eğitim kademelerinin düzeyine paralel yoğunluğu giderek artan konular bulunmaktadır. Hayat Bilgisi, Sosyal Bilgiler, Coğrafya, Fen Bilimleri, Fen ve Teknoloji, Biyoloji, Sağlık Bilgisi ve Kimya derslerinin ünitelerinde çevre ve doğa konusunda ilişkilendirmeler yapılmakta, doğrudan veya dolaylı birtakım kazanımlara yer verilmektedir. ${ }^{9-11} \mathrm{Bu}$ çalışmada, kişilik yapısı oluşmaya, sosyal/toplumsal bir birey olarak varlığını göstermeye başlayan ergenlerde çevresel risk algısının ve bazı değişkenler ile ilişkisinin incelenmesi amaçlanmıştır.

\section{MATERYAL VE METOT}

\section{Araştırmanın Tipi}

$\mathrm{Bu}$ araştırma, tanımlayıcı ve kesitsel tipte bir çalışmadır.

\section{Araştırmanın Evren ve Örneklemi}

Araştırmanın evrenini, Muğla ili Menteşe Şifa Hatun Muğla Mesleki ve Teknik Anadolu Lisesi ve Yatağan - Yatağan Mesleki ve Teknik Anadolu Lisesi'nde öğrenim gören öğrenciler oluşturmuştur ( $\mathrm{N}=525)$. Araştırmada örnekleme yöntemine gidilmemiş öğrencilerin tamamı alınmıştır. Ulaşılabilen, araştırma konusunda bilgilendirilen ve araştırmaya gönüllü katılan 473 öğrenciden veriler toplanmıştır. Araştırmaya katılım oranı \%91'dir.

\section{Verilerin Toplanması}

Veriler Ocak-Mart 2015 tarihleri arasında tarihleri arasında araştırmacılar tarafından, sınıf ortamında, anket yöntemi ile toplanmıştır. Veriler öz bildirime dayalıdır. Veri toplama formu olarak; "Tanımlayıcı Özellikler Soru Formu" ve "Çevresel Risk Algısı Ölçeği (ÇRAÖ)" kullanılmıştır.

Tanımlayıcı Özellikler Soru Formu: Araştırmacı tarafından, literatür doğrultusunda geliştirilen formda; yaş, cinsiyet, sınıf, aile tipi, kardeş sayısı, annebabanın eğitim durumu, en uzun süre yaşanılan yer, gelir durumunu sorgulayan 10 soru ve çevre ile ilgili ailede konuşulması, ilgini çekme, eğitim alma, bilimsel etkinliğe 
katılma, kuruluşa üye olma durumunu sorgulayan beş soru olmak üzere toplam 15 soru yer almıştır. Çevresel Risk Algısı Ölçeği: Türkçeye Altınoğlu ve Atav (2009) tarafından uyarlanan ÇRAÖ, 24 maddeden oluşan, yedili likert tipi bir ölçektir. Ölçekten alınabilecek en yüksek madde toplam puan ortalaması yedi, en düşük birdir. Ölçekten alınan puan ortalamasının artması çevresel risk algısının yüksek olduğunu, azalması ise düşük olduğunu göstermektedir. Ölçeğin cronbach alpha katsayısı 0,89 'dur. Ölçeğin “ekolojik riskler", "kimyasal atık riski", "küresel çevre riskleri" ve "kaynakların tükenmesi riski" olmak üzere dört alt boyutu bulunmaktadır. ${ }^{12}$ Bu çalışmada ölçek Cronbach alpha katsayısı 0,97 olarak belirlenmiştir.

\section{Verilerin Analizi}

Verilerin değerlendirmesi SPSS 20,0 paket programında gerçekleştirilmiştir. Verilerin analizinde, tanımlayıcı istatistikler (sayı, yüzde, ortalama, standart sapma), bağımsız guruplarda t testi ve tek yönlü varyans analizi; gruplar arasındaki farklılıkları saptamak için Tukey ve Hochberg testi kullanılmıştır. Sonuçlar \%95 güven aralığında ve $p<0,05$ anlamlılık düzeyinde değerlendirilmiştir.

\section{Araştırmanın Etik Yönü}

Araştırma için ölçek sahiplerinden kullanım izni, Muğla İl Milli Eğitim Müdürlüğü'nden kurum izni (Tarih: 19/022015, Say1: 70004082/20/1894731), Muğla Sitkı Koçman Üniversitesi Bilimsel Araştırmalar ve Yayın Etiği Kurulu'ndan etik kurul izni (Tarih: 07.01.2015, Karar no: 1) ve katılımcıların aydınlatılmış onamları alınmıştır.

\section{BULGULAR VE TARTIŞMA}

Araştırma kapsamına alınan öğrencilerin yaş ortalamasının $16,22 \pm 1,07, \% 70,2$ 'sinin kadın ve \%29,4'ünün birinci, \%27,7'sinin ikinci, \%24,9'unun üçüncü, \%18,0'inin dördüncü sınıf olduğu saptanmıştır. Annelerin $\% 73,4$ 'ü, babaların \%63,6'sının ilköğretim mezunu oldukları ve \%67,2'sinin gelir-gider durumunun eşit olduğu belirlenmiştir. Öğrencilerin \%45,9'unun en uzun süre köy/kasabada yaşadığı, \%86,5'inin çekirdek aileye ve \%85,6'sının 2-3 kardeşe sahip olduğu saptanmıştır (Tablo 1).

Tablo 1. Öğrencilerin Sosyo-Demografik Özelliklerinin Dağılımı

\begin{tabular}{lcc}
\hline Değişkenler & Sayı & \% \\
\hline Yaş & \multicolumn{2}{c}{$16,22 \pm 1,07$} \\
\hline Cinsiyet & 332 & 70,2 \\
Kız & 141 & 29,8 \\
Erkek & & \\
\hline Sınıf & 139 & 29,4 \\
1, sınıf & 131 & 27,7 \\
2, sınıf & 118 & 24,9 \\
3, sınıf & 85 & 18,0 \\
4, sinıf & & \\
\hline Aile Tipi & 409 & 86,5 \\
Çekirdek aile & 44 & 9,3 \\
Geniş aile & 20 & 4,2 \\
Parçalanmış aile & &
\end{tabular}

Tablo 1 (Devamı), Öğrencilerin SosyoDemografik Özelliklerinin Dağılımı

\begin{tabular}{lrr}
\hline Değişkenler & Sayı & \% \\
\hline Kardeş Sayısı & & \\
Tek çocuk & 33 & 7,0 \\
2-3 kardeş & 405 & 85,6 \\
4 Kardeş ve üzeri & 35 & 7,4 \\
\hline Annenin Eğitim Durumu & & \\
İlköğretim & 347 & 73,4 \\
Lise & 112 & 23,7 \\
Üniversite & 14 & 2,9 \\
\hline
\end{tabular}

\begin{tabular}{lrc}
\hline Babanın Eğitim Durumu & & \\
İlköğretim & 301 & 63,7 \\
Lise & 117 & 24,7 \\
Üniversite & 55 & 11,6 \\
\hline Yerleşim Birimi & & \\
İl merkezi & 131 & 27,7 \\
İlçe merkezi & 125 & 26,4 \\
Köy/kasaba & 217 & 45,9 \\
\hline Gelir Durumu & & \\
Gelir giderden az & 99 & 20,9 \\
Gelir gidere denk & 318 & 67,2 \\
Gelir giderden fazla & 56 & 11,8 \\
\hline Toplam & $\mathbf{4 7 3}$ & $\mathbf{1 0 0}$ \\
\hline
\end{tabular}

Çevre konusunun öğrencilerin \%74,8'i ailesinde konuşulduğunu, \%72,7'si ilgisini çektiğini, \%50,3'ü derslerde işlendiğini, 
\%33,8'i bilimsel etkinliğe katıldığını, \%8,0’i bir çevre kuruluşuna üye olduğunu belirtmiştir (Tablo 2).

Tablo 2. Öğrencilerin Çevre Konularına Yönelik Görüşlerinin Dağılımı

\begin{tabular}{lcccc}
\hline \multirow{2}{*}{\multicolumn{1}{c}{ Değişkenler }} & \multicolumn{2}{c}{ Evet } & \multicolumn{2}{c}{ Hayır } \\
\cline { 2 - 5 } & $\mathbf{n}$ & $\boldsymbol{\%}$ & $\mathbf{n}$ & $\boldsymbol{\%}$ \\
\hline Ailede konuşulması & 354 & 74,8 & 119 & 25,2 \\
\hline $\begin{array}{l}\text { Konunun ilgisini } \\
\text { çekmesi }\end{array}$ & 344 & 72,7 & 129 & 27,3 \\
\hline Derslerde eğitim alma & 238 & 50,3 & 235 & 49,7 \\
\hline $\begin{array}{l}\text { Bilimsel etkinliğe } \\
\text { katılma }\end{array}$ & 160 & 33,8 & 313 & 66,2 \\
\hline Bir kuruluşa üye olma & 38 & 8,0 & 435 & 92,0 \\
\hline
\end{tabular}

Öğrencilerin ÇRAÖ puan ortalamasının $5,75 \pm 1,23$ olduğu, ölçek alt boyutlarından $5,88 \pm 1,21$ puan ortalaması ile en yüksek algının kimyasal atık riskinde olduğu ve bunu sırasıyla küresel çevre riskleri $(5,81 \pm 1,32)$, ekolojik riskler $(5,78 \pm 1,28)$ kaynakların tükenme riski $(5,48 \pm 1,60)$ puan ortalamalarının takip ettiği belirlenmiştir (Tablo 3).

Tablo 3. Öğrencilerin Çevresel Risk Algısı Toplam Puan Ortalamaları

\begin{tabular}{|c|c|c|}
\hline \multicolumn{2}{|c|}{ Ölçekler } & $\mathbf{X} \pm \mathrm{SS}$ \\
\hline \multicolumn{2}{|c|}{ Çevresel Risk Algısı Ölçeği } & $5,75 \pm 1,23$ \\
\hline \multirow{4}{*}{ 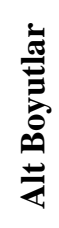 } & Küresel Çevre Riskleri & $5,81 \pm 1,32$ \\
\hline & Kimyasal Atık Riski & $5,88 \pm 1,21$ \\
\hline & Ekolojik Riskler & $5,78 \pm 1,28$ \\
\hline & Kaynakların Tükenme Riski & $5,48 \pm 1,60$ \\
\hline
\end{tabular}

Bu araştırmada öğrencilerin ÇRAÖ toplam puan ortalamasinın orta düzeyin üzerinde olduğu belirlenmiş olup, ölçek madde puan ortalamalarına göre ergenler tarafından çevresel risklerin önemli olarak algılandığ 1 söylenebilir. Benzer şekilde ÇRAÖ toplam puan ortalamasını Sam ve arkadaşları (2010) üniversite öğrencilerinde $4,23,{ }^{14}$ Kaya ve arkadaşları (2012) öğretmen adaylarında $4,32 \pm 0,61,{ }^{15}$ Sayan ve Kaya (2016) hemşirelik öğrencilerinde $6,04 \pm 0,81,{ }^{16}$ Selçuk ve arkadaşları (2016) hemşirelik öğrencilerinde $4,9 \pm 0,9^{17}$ tespit ederek ortalamanın üzerinde bulmuştur.

Öğrencilerin ÇRAÖ’ye ait 23 maddenin puan ortalamalarından en yüksek ilk üç riskin kimyasal atık riski alt boyutuna ait ve bunların sirasiyla kanalizasyon $(6,02 \pm 1,38)$, radyasyon $(5,99 \pm 1,35)$ ve tehlikeli atıklar $(5,94 \pm 1,35)$ riski olduğu belirlenmiştir. En düşük ilk üç riskin ise kaynakların tükenmesi riskine ait ve bunların sırasıyla aşırı otlatma $(5,33 \pm 1,81)$, ticari balıkçılık $(5,37 \pm 1,83)$ ve sportif avlanma $(5,58 \pm 1,73)$ riski olduğu saptanmıştır (Tablo 4). Ölçek alt boyutlarından Kimyasal Atık Riskinin en yüksek puan ortalamasina sahip olduğu belirlenmiş ve burada algılarda sirasıyla kanalizasyon, radyasyon, tehlikeli atıklar, kalıcı zehirli organik bileşikler, ağır metaller, ötrofikasyon ve pestisitlerin izlediği görülmüştür. Muğla ili 2017 yılı çevre durum raporu sonuçlarında çalışma sonuçlarımıza benzer olarak kanalizasyon sisteminin ve merkezi atık su arıtma tesislerinin yetersiz olması birinci öncelikli çevre sorunu olarak belirtilmiştir. Katı atık depolama tesislerinin yetersizliği ikinci, termik santrallerinin çıkardığı baca gazları ve 1sınmadan kaynaklanan hava kirliliği üçüncü öncelikli sorun olarak değerlendirilmiştir. ${ }^{18}$ Maddelerden alınan puanların yüksekliği ve rapor sonuçları Muğla ilinin mevcut çevre sorunlarına yönelik ergenlerin farkındalıklarının olduğunu göstermektedir. Yine raporda orman, mera, sulak alan, kıy,, biyolojik çeşitlilik ve habitat kaybı gibi nedenlerle doğal çevrenin tahribatı en son öncelikli sorun olarak yer alırken ${ }^{18}$ bu çalışmada da aşırı otlatma, ticari balıkçılık, sportif avlanma maddelerinin yer aldığ1 kaynakların tükenme riski puan ortalamasının en düşük olduğu belirlenmiştir.

Araştırma sonuçlarıyla uyumlu olarak çeşitli çalışmalarda da en önemli görülen çevre riskinin kimyasal atıklardan kaynaklanan riskler olduğu tespit edilmiş; ilk üçü sırayla Slimak ve Dietz (2006) tehlikeli atık alanları, kalıcı zehirli organik bileşikler, kanalizasyon; ${ }^{19}$ Sam ve arkadaşları (2010) radyasyon, tehlikeli atık alanları ve kanalizasyon; ${ }^{14}$ Sayan ve Kaya (2016) radyasyon, tehlikeli atıklar, genetiği değiştirilmiş tarım ürünleri ${ }^{16}$ olarak belirlemiştir. Çevre sağlı̆̆ına yönelik bilgi kaynaklarının ergenlerin risk alg1s1 sıralamasının oluşumunda etkili olduğunu düşündürmektedir. Özellikle görsel medyada 
çevresel risk konularının ilk sıralarda yer er aldığ1 ve böylece ilgili riskler hakkında duyarlılığın daha çok olduğu tahmin edilmektedir. Konuyla ilgili yapılan çalışmalarda, araştırmaya katılanların algılarının zamana göre değiştiği, yaşadıkları bölgeye ait çevresel riskleri daha çok ön plana çıkardıkları ve bunlarla ilgili daha duyarlı oldukları belirtilmektedir. ${ }^{12,14-17,20}$

Tablo 4. Öğrencilerin Çevresel Risk Algısı Ölçeği'ne Ait Puan Ortalamaları

\begin{tabular}{clcccc}
\hline $\begin{array}{c}\text { Soru } \\
\text { No }\end{array}$ & \multicolumn{1}{c}{ Risk Maddeleri } & $\begin{array}{c}\text { Alt } \\
\text { boyutlar }\end{array}$ & Ortalama & $\begin{array}{c}\text { Standart } \\
\text { Sapma }\end{array}$ & Suralama \\
\hline $\mathbf{1}$ & Asit yağmurları & KÇR & 5,85 & 1,51 & 5 \\
\hline $\mathbf{2}$ & Sera etkisi & KÇR & 5,90 & 1,38 & 4 \\
\hline $\mathbf{3}$ & Ozon tabakasının incelmesi & KÇR & 5,78 & 1,48 & 12 \\
\hline $\mathbf{4}$ & Petrol çıkarma & KÇR & 5,70 & 1,45 & 16 \\
\hline $\mathbf{5}$ & Tehlikeli atıklar & KAR & 5,94 & 1,35 & 3 \\
\hline $\mathbf{6}$ & Radyasyon & KAR & 5,99 & 1,35 & 2 \\
\hline $\mathbf{7}$ & Kalıcı zehirli organik bileşikler & KAR & 5,84 & 1,48 & 7 \\
\hline $\mathbf{8}$ & Ağır metaller & KAR & 5,83 & 1,38 & 8 \\
\hline $\mathbf{9}$ & Pestisitler & KAR & 5,64 & 1,54 & 18 \\
\hline $\mathbf{1 0}$ & Ötrofikasyon & KAR & 5,74 & 1,50 & 15 \\
\hline $\mathbf{1 1}$ & Kanalizasyon & KAR & 6,02 & 1,38 & 1 \\
\hline $\mathbf{1 2}$ & Genetiği değiştirilmiş tarım ürünleri & ER & 5,80 & 1,48 & 10 \\
\hline $\mathbf{1 3}$ & İstilacı türler & ER & 5,75 & 1,50 & 14 \\
\hline $\mathbf{1 4}$ & Ormanlarda kesim & ER & 5,80 & 1,45 & 11 \\
\hline $\mathbf{1 5}$ & Habitatların bozulması & ER & 5,82 & 1,49 & 9 \\
\hline $\mathbf{1 6}$ & Baraj yapımı & ER & 5,69 & 1,57 & 17 \\
\hline $\mathbf{1 7}$ & Sulak alanların kaybı & ER & 5,78 & 1,53 & 13 \\
\hline $\mathbf{1 8}$ & İç suların kimyasal kirliliği & ER & 5,85 & 1,44 & 6 \\
\hline $\mathbf{1 9}$ & Açık madencilik & KTR & 5,64 & 1,62 & 19 \\
\hline $\mathbf{2 0}$ & Aşırı otlatma & KTR & 5,33 & 1,81 & 23 \\
\hline $\mathbf{2 1}$ & Spportif avlanma & KTR & 5,58 & 1,73 & 21 \\
\hline $\mathbf{2 2}$ & Tícari balıkçılık & KTR & 5,37 & 1,83 & 22 \\
\hline $\mathbf{2 3}$ & Nüfus artışı & KTR & 5,62 & 1,70 & 20 \\
\hline & & & & &
\end{tabular}

KÇR: Küresel Çevre Riski, KAR: Kimyasal Attk Riski, ER: Ekolojik Riskler, KTR: Kaynakların Tükenmesi Riski

Öğrencilerin bazı değişkenler ile ÇRAÖ madde puan ortalamaları incelenmiştir (Tablo 5). Literatürde çevresel risk algıları üzerinde sosyodemografik özelliklerden yaşın, cinsiyetin, sınıfın, aile tipinin, kardeş sayısının, anne-baba eğitim durumunun, yaşanılan bölgenin, gelir durumunun, çevre konularına ilgi durumunun, çevre eğitimi almanın, çevre kuruluşlarına üye olmanın etkili olabileceği vurgulanmaktadır. ${ }^{12,14,20-25}$ Ergenlerin cinsiyeti ile çevresel risk algısı puan ortalamaları arasında anlamlı bir farklılık görülmemiştir ( $p>0,05)$. Bu bulguyu destekleyen çalışma sonuçları olmakla birlikte, ${ }^{15-25-27}$ bu konuda yapılan birçok çalışmada cinsiyetin, çevre risk algısı üzerinde etkili olduğu ve kadınlarda daha yüksek olduğu bulunmuştur. ${ }^{14,16,17,20,28}$ Dördüncü sınıf öğrencilerinin diğer sınıflara göre daha yüksek risk algısı puan ortalamalarına sahip oldukları görülmüştür $(\mathrm{p}<0,001)$. Bu sonuç yaşla birlikte sınıf düzeyi de arttıkça bilgi birikiminin yükselmesine bağlı olarak ergenlerde çevresel riskler konusundaki farkındalığın ve çevreye karşı duyarlılığın daha da arttığını düşündürmektedir. Yı1maz ve arkadaşları (2002) ortaöğretim ve üniversite öğrencileri ile yaptıkları çalışmada; öğrencilerin çevreyi korumanın anayasal bir zorunluluk olduğunun bilincinde olduğunu ve bu bilincin üst sınıflarda öğrenim gören öğrencilerle doğru 
orantılı olarak arttığını belirtmiștir. ${ }^{29}$ Aile ortamı, sosyalleşme sürecinin başladığı en önemli ortamlardan biri olup çevre sorunlarına karşı gerekli hassasiyetin ve sorumluluk bilincinin kazanılabileceği önemli bir ortamdır. $\mathrm{Bu}$ çalışmada aile tipinin ve kardeş sayısının ergenlerin çevre ile ilgili risk algılarını etkilemediği görülmüştür $(\mathrm{p}>0,05)$. Bazı çalışmalarda geniş aile tipinin ve kardeş sayısının artması kişilerin çevresel risk algılarını arttırdığı belirtilmiştir. Çalışmanın önemli sonuçlarından bir tanesi de gelir düzeyi düşük öğrencilerin ÇRAÖ toplam ve ekolojik riskler alt boyutu puan ortalamalarının gelir düzeyi yüksek olan öğrencilere göre daha fazla olmasıdır $(\mathrm{p}<0,05)$. Yapılan bazı çalışmalarda öğrencilerin gelir düzeyi ile çevreye yönelik risk algıları arasında anlamlı fark görülmemiştir. ${ }^{3,20,25}$ Ailede ekonomik seviye arttıkça paralel olarak çocuklara sağlanan eğitim imkanları da artmakta olup, ergenlerin çevreye yönelik risk algılarının olumlu yönde etkilenmesi gerektiği düşünülmektedir. Fakat bu durumun tam tersi sonuç çıkması çocukların çevreden koparılarak kapalı ortamlarda teknolojinin daha fazla olduğu imkanların sunulmasından kaynaklandığını düşündürmektedir. Öğrencilerin ebeveynlerinin eğitim düzeyi ile çevresel risk algıları arasında literatüre benzer şekilde fark olmadığı saptanmıştır ( $p>0,05) .{ }^{3,25,30}$ Ailelerin çocuklarına çevre konusunda doğru rol modeli olabilmeleri için ebeveyn eğitimlerinin yapılması gerektiği düşünülmektedir.

Tablo 5'te öğrencilerin bazı değişkenler ile ÇRAÖ alt boyutlarından aldıkları madde puan ortalamaları incelenmiştir. Dördüncü sınıf öğrencilerin diğer sinıflara göre $(p<0,001)$, ailede çevre konusunda konuşanların $(\mathrm{p}<0,01)$, çevre konusu ilgisini çekenlerin $(p<0,001)$ ve derslerde eğitim alanların $(p<0,05)$ "küresel çevre riski" ve "kimyasal atık riski" alt boyutlarından aldıkları madde puan ortalamasının daha yüksek olduğu belirlenmiştir. Dördüncü sınıf öğrencilerin diğer sinıflara göre $(p<0,001)$, gelir durumu az olanların gelir giderden fazla olanlara göre $(\mathrm{p}<0,05), \quad$ ailede çevre konusunda konuşanların $(\mathrm{p}<0,01)$, çevre konusu ilgisini çekenlerin $(p<0,001)$ ve derslerde eğitim alanların $(p<0,05)$ "ekolojik riskler" alt boyutundan aldikları madde puan ortalamasının daha yüksek olduğu görülmüştür. Çevre konularını ailesinde konuşan, çevre konuları ilgisini çeken ve derslerde çevre ile ilgili eğitim alan ergenlerin çevresel risk algısı ve alt boyutları puanları daha yüksek çıkmıştır. Öğrencilerin çevre konularına yönelik ilgisinin olması, çevre sorunlarının aile ortamında konuşulması ve çevresel risk algılarını etkilemesi beklendik bir durumdur. Yetişen bireylerin çevre konularına olan farkındalığının artırılması ve çevre sorunlarına stratejik çözümler geliştirebilmesi için ilkokuldan başlayarak tüm eğitim basamaklarında çevre ile ilgili etkin derslerin olmasının gerektiği düşünülmektedir. Ergenlerde herhangi bir çevre kuruluşuna üye olma durumu ve çevre konusunda bir bilimsel etkinliğe katılma durumu ile çevresel risk algısı ve alt boyut puan ortalamaları arasında literatüre benzer şekilde bir fark görülmemiştir. ${ }^{25,31} \mathrm{Bu}$ yüzden ergenlere çevreyle ilgili kuruluşların tanıtılması, ulaşılabilirliğinin sağlanması, seminer, panel, konferans gibi bilimsel çalışmalar düzenlenmesi konusunda desteklenmelidir. 
Tablo 5. Öğrencilerin Bireysel Özellikleri ile Çevresel Risk Algısı Ölçeği Toplam ve Alt Boyutlarına Ait Madde Puan Ortalamalarının Karşılaştırılması

\begin{tabular}{|c|c|c|c|c|c|c|c|c|c|c|c|}
\hline Değişkenler & Özellikler & ÇRAÖ & Test/p & KÇR & Test/p & KAR & Test/p & ER & Test/p & KTR & Test/p \\
\hline \multirow{2}{*}{ Cinsiyet } & $\mathrm{K} 1 \mathrm{z}$ & $5,82 \pm 1,15$ & $1,686^{1}$ & $5,88 \pm 1,25$ & $1,767^{1}$ & $5,92 \pm 1,16$ & $1,067^{1}$ & $5,86 \pm 1,17$ & $1,966^{1}$ & $5,55 \pm 1,52$ & $1,432^{1}$ \\
\hline & Erkek & $5,59 \pm 1,39$ & 0,093 & $5,63 \pm 1,48$ & 0,079 & $5,78 \pm 1,33$ & 0,286 & $5,58 \pm 1,50$ & 0,051 & $5,30 \pm 1,78$ & 0,154 \\
\hline \multirow{4}{*}{ Sinıf } & 1. $\sin 1 f^{\mathrm{a}}$ & $5,48 \pm 1,43$ & & $5,51 \pm 1,52$ & & $5,62 \pm 1,46$ & \multirow{4}{*}{$\begin{array}{c}11,893^{2} \\
\mathbf{0 , 0 0 0 * * *} \\
\boldsymbol{d}>\boldsymbol{a}, \boldsymbol{b}, \boldsymbol{c}\end{array}$} & $5,56 \pm 1,50$ & & $5,10 \pm 1,77$ & \multirow{4}{*}{$\begin{array}{r}8,131^{2} \\
\mathbf{0 , 0 0 0 * * *} \\
\boldsymbol{d}>\boldsymbol{a}, \boldsymbol{b}, \boldsymbol{c}\end{array}$} \\
\hline & 2. $\sin 1 f^{b}$ & $5,78 \pm 1,22$ & $16,943^{2}$ & $5,90 \pm 1,28$ & $11,108^{2}$ & $5,89 \pm 1,16$ & & $5,79 \pm 1,25$ & $10,553^{2}$ & $5,54 \pm 1,61$ & \\
\hline & 3. $\sin ^{f^{c}}$ & $5,56 \pm 4,07$ & $\begin{array}{c}0,000 * * * \\
d>a, b, c\end{array}$ & $5,58 \pm 1,23$ & $\begin{array}{c}0,000^{* * * *} \\
d>a, b, c\end{array}$ & $5,70 \pm 1,04$ & & $5,56 \pm 1,13$ & $\begin{array}{c}0,000 * * * \\
d>a, b, c\end{array}$ & $5,37 \pm 1,46$ & \\
\hline & 4. $\sin 1 f^{\mathrm{d}}$ & $6,41 \pm 0,80$ & & $6,46 \pm 0,87$ & & $6,15 \pm 1,25$ & & $6,44 \pm 0,88$ & & $6,15 \pm 1,25$ & \\
\hline \multirow{3}{*}{ Aile Tipi } & Çekirdek aile & $5,77 \pm 1,21$ & \multirow{3}{*}{$\begin{array}{c}0,624^{2} \\
0,536\end{array}$} & $5,84 \pm 1,27$ & & $5,90 \pm 1,19$ & \multirow{3}{*}{$\begin{array}{c}0,753^{2} \\
0,472\end{array}$} & $5,80 \pm 1,26$ & & $5,50 \pm 1,59$ & \multirow{3}{*}{$\begin{array}{r}0,288^{2} \\
0,750\end{array}$} \\
\hline & Geniş aile & $5,55 \pm 1,31$ & & $5,44 \pm 1,62$ & $\begin{array}{l}1,812^{2} \\
0,164\end{array}$ & $5,67 \pm 1,25$ & & $5,59 \pm 1,42$ & $\begin{array}{c}0,585^{2} \\
0,558\end{array}$ & $5,40 \pm 1,52$ & \\
\hline & $\begin{array}{l}\text { Parçalanmış } \\
\text { aile }\end{array}$ & $5,75 \pm 1,23$ & & $5,85 \pm 1,63$ & & $5,84 \pm 1,62$ & & $5,88 \pm 1,53$ & & $5,25 \pm 2,03$ & \\
\hline \multirow{3}{*}{$\begin{array}{l}\text { Kardeş } \\
\text { Sayısı }\end{array}$} & Tek çocuk & $5,92 \pm 1,42$ & \multirow{3}{*}{$\begin{array}{c}0,621^{2} \\
0,538\end{array}$} & $5,96 \pm 1,48$ & \multirow{3}{*}{$\begin{array}{c}0,393^{2} \\
0,675\end{array}$} & $5,97 \pm 1,44$ & \multirow{3}{*}{$\begin{array}{c}0,169^{2} \\
0,845\end{array}$} & $5,96 \pm 1,45$ & \multirow{3}{*}{$\begin{array}{c}0,610^{2} \\
0,544\end{array}$} & $5,73 \pm 1,57$ & \multirow{3}{*}{$\begin{array}{c}0,969^{2} \\
0,380\end{array}$} \\
\hline & 2-3 kardeş & $5,72 \pm 1,19$ & & $5,78 \pm 1,29$ & & $5,86 \pm 1,17$ & & $5,75 \pm 1,24$ & & $5,43 \pm 1,59$ & \\
\hline & $\begin{array}{l}4 \text { Kardeş ve } \\
\text { üzeri }\end{array}$ & $5,89 \pm 1,52$ & & $5,91 \pm 1,51$ & & $5,93 \pm 1,51$ & & $5,92 \pm 1,59$ & & $5,72 \pm 1,77$ & \\
\hline \multirow{3}{*}{$\begin{array}{l}\text { Annenin } \\
\text { Eğitim } \\
\text { Durumu }\end{array}$} & İlköğretim & $5,77 \pm 1,23$ & \multirow{3}{*}{$\begin{array}{c}0,105^{2} \\
0,901\end{array}$} & $5,84 \pm 1,29$ & \multirow{3}{*}{$\begin{array}{c}0,577^{2} \\
0,562\end{array}$} & $5,89 \pm 1,24$ & \multirow{3}{*}{$\begin{array}{c}0,113^{2} \\
0,893\end{array}$} & $5,80 \pm 1,27$ & \multirow{3}{*}{$\begin{array}{c}0,221^{2} \\
0,802\end{array}$} & $5,45 \pm 1,67$ & \multirow{3}{*}{$\begin{array}{l}0,437^{2} \\
0,646\end{array}$} \\
\hline & Lise & $5,72 \pm 1,23$ & & $5,69 \pm 1,43$ & & $5,83 \pm 1,15$ & & $5,71 \pm 1,33$ & & $5,59 \pm 1,35$ & \\
\hline & Üniversite & $5,66 \pm 1,30$ & & $5,80 \pm 1,22$ & & $5,82 \pm 1,19$ & & $5,71 \pm 1,29$ & & $5,26 \pm 1,67$ & \\
\hline \multirow{3}{*}{$\begin{array}{l}\text { Babanın } \\
\text { Eğitim } \\
\text { Durumu }\end{array}$} & İlköğretim & $5,75 \pm 1,24$ & \multirow{3}{*}{$\begin{array}{c}0,144^{2} \\
0,866\end{array}$} & $5,83 \pm 1,30$ & \multirow{3}{*}{$\begin{array}{r}0,396^{2} \\
0,674\end{array}$} & $5,85 \pm 1,25$ & \multirow{3}{*}{$\begin{array}{c}0,414^{2} \\
0,661\end{array}$} & $5,78 \pm 1,30$ & \multirow{3}{*}{$\begin{array}{c}0,236^{2} \\
0,790\end{array}$} & $5,48 \pm 1,63$ & \multirow{3}{*}{$\begin{array}{r}0,008^{2} \\
0,992\end{array}$} \\
\hline & Lise & $5,72 \pm 1,31$ & & $5,71 \pm 1,46$ & & $5,88 \pm 1,24$ & & $5,74 \pm 1,37$ & & $5,47 \pm 1,63$ & \\
\hline & Üniversite & $5,83 \pm 0,98$ & & $5,86 \pm 1,14$ & & $6,01 \pm 0,92$ & & $5,88 \pm 1,02$ & & $5,50 \pm 1,39$ & \\
\hline & İl merkezi & $5,87 \pm 1,04$ & & $5,90 \pm 1,18$ & & $6,01 \pm 0,97$ & & $5,87 \pm 1,14$ & & $5,66 \pm 1,38$ & \\
\hline $\begin{array}{l}\text { Yerleşim } \\
\text { Birimi }\end{array}$ & İlçe merkezi & $5,64 \pm 1,24$ & $\begin{array}{l}1,116^{2} \\
0,328\end{array}$ & $5,69 \pm 1,32$ & $\begin{array}{c}0,818^{2} \\
0,442\end{array}$ & $5,75 \pm 1,21$ & $\begin{array}{l}1,520^{2} \\
0,220\end{array}$ & $5,67 \pm 1,30$ & $\begin{array}{c}0,788^{2} \\
0,456\end{array}$ & $5,39 \pm 1,52$ & $\begin{array}{l}1,192^{2} \\
0,305\end{array}$ \\
\hline & Köy/kasaba & $5,74 \pm 1,33$ & & $5,82 \pm 1,40$ & & $5,87 \pm 1,34$ & & $5,78 \pm 1,35$ & & $5,42 \pm 1,76$ & \\
\hline & $\begin{array}{l}\text { Gelir giderden } \\
\mathrm{az}^{\mathrm{a}}\end{array}$ & $5,95 \pm 1,01$ & & $6,05 \pm 1,16$ & & $6,01 \pm 1,16$ & & $6,02 \pm 1,11$ & & $5,64 \pm 1,53$ & \\
\hline $\begin{array}{l}\text { Gelir } \\
\text { Durumu }\end{array}$ & $\begin{array}{l}\text { Gelir gidere } \\
\text { denk }^{\mathrm{b}}\end{array}$ & $5,75 \pm 1,26$ & $\begin{array}{c}3,224^{2} \\
\mathbf{0 , 0 4 1} \\
\boldsymbol{a}>\boldsymbol{c}\end{array}$ & $5,81 \pm 1,32$ & $\begin{array}{c}5,068^{2} \\
1,735\end{array}$ & $5,89 \pm 1,22$ & $\begin{array}{c}2,367^{2} \\
0,095\end{array}$ & $5,89 \pm 1,22$ & $\begin{array}{c}3,513^{2} \\
\mathbf{0 , 0 3 1} * \\
\boldsymbol{a}>\boldsymbol{c}\end{array}$ & $5,46 \pm 1,65$ & $\begin{array}{c}1,035^{2} \\
0,356\end{array}$ \\
\hline & $\begin{array}{l}\text { Gelir giderden } \\
\text { fazla }^{\mathrm{c}}\end{array}$ & $5,42 \pm 1,25$ & & $5,35 \pm 1,51$ & & $5,57 \pm 1,21$ & & $5,57 \pm 1,21$ & & $5,26 \pm 1,42$ & \\
\hline Ailede & Evet & $5,86 \pm 1,16$ & $3,044^{1}$ & $5,92 \pm 1,27$ & $2,986^{1}$ & $5,98 \pm 1,15$ & $3,119^{1}$ & $5,89 \pm 1,21$ & $0,108^{1}$ & $5,57 \pm 1,56$ & $2,190^{1}$ \\
\hline konuşulması & Hayır & $5,43 \pm 1,38$ & $0,003^{* *}$ & $5,48 \pm 1,43$ & $0,003 * *$ & $5,55 \pm 1,35$ & $0,002 * *$ & $5,44 \pm 1,44$ & $0,002 * *$ & $5,19 \pm 1,68$ & $0,030 *$ \\
\hline Konunun & Evet & $5,92 \pm 1,07$ & $4,406^{1}$ & $5,99 \pm 1,16$ & $4,416^{1}$ & $6,06 \pm 1,04$ & $4,591^{1}$ & $5,96 \pm 1,12$ & $4,543^{1}$ & $5,61 \pm 1,51$ & $2,921^{1}$ \\
\hline çekmesi & Hayır & $5,29 \pm 1,50$ & $0,000 * * *$ & $5,31 \pm 1,59$ & $0,000 * * *$ & $5,40 \pm 1,49$ & $0,000^{* * * *}$ & $5,29 \pm 1,55$ & 0,000 *** & $5,13 \pm 1,77$ & $0,004 * *$ \\
\hline $\begin{array}{l}\text { Bilimsel } \\
\text { etkinliğe }\end{array}$ & Evet & $5,86 \pm 1,11$ & $1,505^{1}$ & $5,91 \pm 1,19$ & $1,185^{1}$ & $5,96 \pm 1,13$ & $1,078^{1}$ & $5,88 \pm 1,16$ & $1,214^{1}$ & $5,68 \pm 1,42$ & $2,053^{1}$ \\
\hline katılma & Hayır & $5,69 \pm 1,29$ & 0,133 & $5,75 \pm 1,39$ & 0,237 & $5,83 \pm 1,25$ & 0,282 & $5,73 \pm 1,34$ & 0,225 & $5,37 \pm 1,68$ & $0,041^{*}$ \\
\hline Derslerde & Evet & $5,89 \pm 1,10$ & $2,428^{1}$ & $5,95 \pm 1,20$ & $2,374^{1}$ & $6,01 \pm 1,11$ & $2,486^{1}$ & $5,93 \pm 1,14$ & $2,547^{1}$ & $5,59 \pm 1,54$ & $1,623^{1}$ \\
\hline eğitim alma & Hayır & $5,61 \pm 1,34$ & $0,016^{*}$ & $5,66 \pm 1,43$ & $0,018^{*}$ & $5,74 \pm 1,30$ & $0,013^{*}$ & $5,63 \pm 1,40$ & $0,011^{*}$ & $5,36 \pm 1,65$ & 0,105 \\
\hline $\begin{array}{l}\text { Bir } \\
\text { kurulușa }\end{array}$ & Evet & $5,96 \pm 1,14$ & $1,093^{1}$ & $5,95 \pm 1,20$ & $0,690^{1}$ & $5,98 \pm 1,16$ & $0,594^{1}$ & $5,98 \pm 1,13$ & $0,993^{1}$ & $5,89 \pm 1,38$ & $1,660^{1}$ \\
\hline üye olma & Hayır & $5,73 \pm 1,24$ & 0,275 & $5,79 \pm 1,33$ & 0,491 & $5,87 \pm 1,22$ & 0,594 & $5,76 \pm 1,30$ & 0,321 & $5,44 \pm 1,61$ & 0,098 \\
\hline
\end{tabular}

ÇAÄ̈: Çevresel Risk Algısı Ölçeği, KÇR: Küresel Çevre Riski, KAR: Kimyasal Atık Riski, ER: Ekolojik Riskler, KTR: Kaynakların Tükenmesi Riski. ${ }^{\prime}$ Bağımsız değişkenlerde t test 


\section{SONUÇ VE ÖNERILLER}

Sonuç olarak araştırmaya katılan öğrencilerin çevresel risk algısının iyi düzeyde olduğu; alg1 madde puan ortalamasının kanalizasyon, radyasyon ve tehlikeli atıklarda en yüksek; aşırı otlatma, ticari balıkç1lık ve sportif avlanmada en düşük olduğu görülmüştür. Sınıf düzeyinin, gelir durumunun, çevre konusunun ilgisini çekmenin, ailede konuşulmasının, lisedeki derslerde işleniyor olmasının ergenlerin algısını etkilemektedir. Tüm okul müfredatlarında çevre sağlı̆̆ derslerinin olması ve yaygınlaştırılmasının, çevre ile ilgili özel günlerde çevre sorunları ve çözüm önerilerine yönelik seminer, panel, konferans gibi etkinlik programlarının oluşturulması ve bu programlara öğrencilerin katılımının sağlanmasının konuyla ilgili farkındalığı artıracağı, dolayısıyla toplum sağlığına katkı sağlayacağı düşünülmektedir.

KAYNAKLAR

1. Celik S, Başaran T, Gökalp MR, Yesildal M, Han O. (2016) Hemșirelik ve Tıp Öğrencilerinin Çevre Sorunlarına Yönelik Tutumları. Sağlık Bilimleri ve Meslekleri Dergisi, 3 (2), 91-98.

2. Doğan Y. (2017). Ortaokul öğrencilerinin Cevre Kavramına İlişkin Sezgisel Algıları: Bir Metafor Analizi. Kırşehir Eğitim Fakültesi Dergisi, 18 (1), 721-740.

3. Aydın AH, Çamur Ö. (2017). Avrupa Birliği Cevre Politikaları ve Çevre Eylem Programları Üzerine Bir İnceleme. Bingö Üniversitesi Sosyal Bilimler Enstitüsü Dergisi, 7 (13), 21-44.

4. Çavuşoğlu F, Altay B, Nuriyeva G, Öngör B. (2017). İlköğretim Öğrencilerinin Çevre Bilgi ve Tutumlarının Değerlendirilmesi. Anadolu Hemşirelik ve Sağlık Bilimleri Dergisi, 20 (4), 254-259.

5. Bahar Z, Aydoğdu NG. (2015). Çevre, Sağlık, Araștırma ve Hemșirelik. Dokuz Eylül Üniversitesi Hemșirelik Fakültesi Elektronik Dergisi, 8 (2), 119-122.

6. Özsoy SA, Șimșek H. (2018). Hemșirelik Uygulamalarına Yön Veren Uluslararası Hemşirelik Kuruluşlarının Çevre Sağlığ Yaklaşımları. Anadolu Hemşirelik ve Sağlık Bilimleri Dergisi, $21(1), 51-59$

7. Bodur G, Taşocak G. (2013). Nursing Students' Views About Environmental Sensitivity in Turkey. Journal of Human Sciences, 10 (1), 820-831.

8. Gök E, Afyon A. (2015). İlköğretim Öğrencilerinin Çevre Bilgisi ve çevresel Tutumları Üzerine Alan Araştırması. Journal of Turkish Science Education, 12 (4), 77-93.

9. İncekara S, Tuna F. (2010). Ortaöğretim Öğrencilerinin Cevresel Konularla İlgili Bilgi Düzeylerinin Ölçülmesi: Çankırı İli Örneği. Marmara Coğrafya Dergisi, 22, 168-182.

10. Demir E, Yalçın H. (2014). Türkiye'de Çevre Eğitimi. Türk Bilimsel Derlemeler Dergisi, 7 (2), 07-18.

11. Vural H, Yılmaz S. (2016). Ortaokul Öğrencilerinin Çevre ve Doğa ile İlgili Konularda Bilgi ve Davranış Düzeylerinin Belirlenmesi; Erzurum İli Örneği. Iğdır Üniversitesi Fen Bilimleri Enstitüsü Dergisi, 6 (1), 107-115.

12. Altunoğlu BD, Atav E. (2009). Ortaöğretim Öğrencilerinin Çevre Risk Algısı. Hacettepe Üniversitesi Eğitim Fakültesi Dergisi, 36, 01-11.

13. Kahyaoğlu M. (2016). Türkiye'de Cevre Eğitimi Üzerine Yapılan Araştırmalar: Bir İçerik Analizi Çalışması. Marmara Coğrafya Dergisi., (34), 50-60.

14. Sam N, Gürsakal S, Sam R. (2010). Üniversite Öğrencilerinin Çevresel Risk Algısı ve Çevresel Tutumlarının Belirlenmesi. Akademik Bakış Dergisi, 20, 1-16.
15. Kaya MF, Kahyaoğlu M, Birel GF. (2012). An Evaluation of Elementary Teacher Candidates' Environmental Approaches, Environmental Risk Perceptions and Environmental Behaviours. Procedia - Social and Behavioral Sciences, 55, 655-660.

16. Sayan B, Kaya H. (2016). Assessment of the Environmental Risk Perceptions and Environmental Attitudes of Nursing Students. Contemp Nurse, 52 (6), 771-781.

17. Selçuk KT, Mercan Y, Cevik C. (2016). Hemșirelik Bölümü Öğrencilerinde Çevresel Risk Algısı ve İlişkili Etmenler. Uluslararası Hakemli Hemşirelik Araştırmaları Dergisi, 7, 116135.

18. Muğla Valiliği Çevre ve Şehircilik İl Müdürlüğü. Muğla İli 2017 Yılı Çevre Durum Raporu. (Erișim tarihi: 25 Temmuz 2019, Erişim adresi: https://webdosya.csb.gov.tr/db/ced/icerikler/son-2017-muglail-cevre-durum-raporu-20181103082044.pdf).

19. Slimak MW, Dietz T. (2006). Personal Values, Beliefs, and Ecological Risk Perception. Risk Analysis, 26 (6), 1689-1705.

20. Senyurt A, Temel AB, Özkahraman S. (2011). Üniversite Öğrencilerinin Çevresel Konulara Duyarlılıklarının İncelenmesi. Süleyman Demirel Üniversitesi Sağlık Bilimleri Enstitüsü Dergisi, 2 (1), 8-15.

21. Beyhun NE, Vaizoğlu SA, Mete A, Okur S, Ongun M, Orçan S, ve ark. (2007). Hacettepe Üniversitesi Tip Fakültesi 2005 2006 Öğretim Dönemi Son Sinıf Öğrencilerinde Çevresel Risk Algılama Düzeyi. TSK Koruyucu Hekimlik Bülteni, 6 (5), 345 350.

22. Ek HN, Kılıç N, Öğdüm P, Düzgün G, Şeker S. (2009). Adnan Menderes Üniversitesinin Farklı Akademik Alanlarında Öğrenim Gören İlk ve Son Sınıf Öğrencilerinin Çevre Sorunlarına Yönelik Tutumları ve Duyarlılıkları. Kastamonu Eğitim Dergisi, 17 (1), 125-136.

23. Erol GH, Gezer K. (2006). Prospective of Elementary Schoo Teachers' Attitudes Toward Environment and Environmental Problems. International Journal of Environmental and Science Education, 1 (1), 65-77.

24. Özmen D, Cetinkaya AC, Nehir S. (2005). Üniversite Öğrencilerinin Çevre Sorunlarına Yönelik Tutumları. TSK Koruyucu Hekimlik Bülteni, 4 (6), 330-344.

25. Yurtseven E, Vehid S, Köksal S, Erdoğan MS. (2010). İstanbul Üniversitesi Sağlık Hizmetleri Meslek Yüksek Okulu Öğrencilerinin Çevresel Riskler Konusundaki Duyarlılıkları. Fırat Üniversitesi Sağlık Bilimleri Dergisi, 24 (3), 193-199.

26. Aydın F, Kaya H. (2010). Sosyal Bilimler Lisesi Öğrencilerinin Cevre Duyarlılıklarının Değerlendirilmesi. Marmara Coğrafya Dergisi, 24, 229-257. 
27. Palancı E, Sarıkaya M. (2019). Ortaokul Öğrencilerinin Çevre Risk Algı Puanları ile Fen Bilimleri Dersi Akademik Başarıları Arasındaki İlişkinin Araştırılması. Anadolu Kültürel Araştırmalar Dergisi, 3 (1), 15-25.

28. Kaya E, Akıllı M, Sezek F. (2009). Lise Öğrencilerinin Çevreye Karşı Tutumlarının Cinsiyet Açısından Incelenmesi. Mehmet Akif Ersoy Üniversitesi Eğitim Fakültesi Dergisi, 9 (18), 43-54.

29. Yılmaz A, Morgil İ, Aktuğ P, Göbekli İ. (2002). Ortaöğretim ve Üniversite Öğrencilerinin Çevre, Çevre Kavramları ve Sorunları Konusundaki Bilgileri ve Öneriler. Hacettepe Üniversitesi Eğitim Fakültesi Dergisi, 22 (22), 156-162.
30. Cinar N, Akduran F, Dede C, Altınkaynak S. (2010). Hemşirelik Bölümü Son Sınıf Öğrencilerinin Çevre Sorunlarına Yönelik Tutumları. Maltepe Üniversitesi Hemşirelik Bilim ve Sanatı Dergisi, (Sempozyum Özel Sayısı), 242-252.

31. Özdemir O, Yıldız A, Ocaktan E, Sarışen Ö. (2004). Tıp Fakültesi Öğrencilerinin Çevre Sorunları Konusundaki Farkındalık ve Duyarlılıkları. Ankara Üniversitesi Tıp Fakültesi Mecmuas1, 57 (3), 117-127. 